\title{
The treatment of obstructive azoospermia by intracytoplasmic sperm injection
}

\author{
Sheena E.M. LEWIS \\ School of Medicine, Obstetrics and Gynaecology, Queen's University Belfast, \\ Institute of Clinical Science, Belfast
}

\begin{abstract}
Intracytoplasmic sperm injection (ICSI) allows the treatment of virtually every type of male infertility. Unlike in vitro fertilization (IVF), its success does not depend on sperm concentration, motility or morphology and most of the physical barriers to fertilisation are by-passed. Since ICSI does not require strongly motile sperm, its use has now been expanded to incorporate immature sperm from the testes and epididymides. Successful fertilisation, pregnancies and healthy babies have all been reported. However, concerns about the safety of ICSI remain due to its short clinical history and the lack of testing on animal models.
\end{abstract}

Male fertility potential for assisted reproduction by ICSI cannot be measured by conventional parameters. Sperm DNA integrity is increasingly recognised as a more useful indicator. Studies have shown that sperm with higher levels of DNA damage have lower fertilisation rates after IVF and ICSI. Sperm with DNA damage above a certain threshold are associated with a longer time to conceive in otherwise apparently fertile couples and a higher miscarriage rate. DNA damage has been shown to be associated with impaired embryo cleavage. Our group has shown that sperm DNA from testicular sperm is less fragmented than that from epididymal sperm and suggest its preferred use in ICSI.

In addition to nuclear (n) DNA we also assessed the quality of mitochondrial (mt) DNA from testicular sperm from men with obstructive azoospermia undergoing ICSI. We observed that couples achieving a pregnancy had both less mtDNA deletions and less nDNA fragmentation. We found inverse relationships between pregnancy and sperm mtDNA deletion numbers, size and nDNA fragmentation. No relationships were observed with fertilisation rates. With this knowledge, we designed an algorithm for the prediction of pregnancy based on the quality of sperm nDNA and mtDNA.

Each year 40,000 men have a vasectomy in the UK but every year 2500 request a reversal to begin a second family. For such men, vasectomy reversal has recently been replaced in part by testicular biopsy via fine-needle testicular sperm aspiration (TESA) or percutaneous epididymal sperm aspiration (PESA) performed at an outpatient clinic and subsequently used in ICSI. Since these were previously fertile men it has been assumed that they had 'fertile' sperm. However the assisted conception success rates of these mens partners has not been assessed until recently. We have shown a significant reduction in the clinical pregnancy rates in the partners of men who had had a vasectomy $\geq 10 y$ rs previously. There is also evidence to suggest that spermatogenesis is significantly impaired in vasectomised men. Marked decreases in spermatocytes, spermatids and spermatozoa have been observed. We have found this to be associated with concomitant increases in apoptotic markers, such as Fas, FasL and Bax. The quality of the remaining sperm is also compromised. Sperm DNA from vasectomized men shows substantial damage which increases with time after surgery. This new use of ICSI will be discussed.

Key words : testicular sperm, obstructive azoospermia, vasectomy, nuclear DNA, mitochondrial DNA

\section{Correspondance :}

Dr Sheena E.M. LEWIS - School of Medicine, Obstetrics and Gynaecology, Queen's University Belfast, Institute of Clinical Science, Grosvenor Road, Belfast BT12 6BA -

Tel 442890633987 - Fax 442890328247 -

Email s.e.lewis@qub.ac.uk 


\section{INTRODUCTION}

Intracytoplasmic sperm injection (ICSI) is an invaluable innovation in the treatment of infertile couples, incorporating the use of testicular or epididymal sperm to provide treatment of infertile men with obstructive azoospermia [24, 36, 77]. However, ICSI has removed many of the check points that prevent poor quality or immature sperm from fertilising oocytes. Motility, capacitation, the acrosome reaction and oocyte binding are no longer essential for fertilisation since the sperm is injected directly into the cytoplasm of the oocyte. This has de-emphasised sperm selection by the criteria previously set for in vitro fertilization (IVF) and allowed the arbitrary choice of sperm for injection. For the first time in history, we have perfected a technique that circumvents all these natural barriers to fertilisation thus facilitating the union of potentially defective gametes. It is now generally accepted that male infertility can be passed from infertile fathers to sons born as a result of ICSI. As yet, the effects of ICSI on long term heaith of these children are unknown. Another ramification of the success of ICSI has been a cessation of research into sperm dysfunction as success rates do not appear to be influenced by previous World Health Organisation criteria.

Intracytoplasmic sperm injection offers men with azoospermia their first opportunity to father their own genetic children. Azoospermia is the most severe form of male infertility where sperm are absent from the ejaculate, due either to a genital tract obstruction (obstructive azoospermia) or spermatogenic failure (non-obstructive azoospermia). Its incidence is $1 \%$ in the general male population increasing to $10-15 \%$ of infertile men [85]. Forty-five to $75 \%$ of these men have obstructive azoospermia $[57,85]$ usually caused by congenital absence of vas deferens (CBAVD), post-infective epididymitis (from gonorrhoea, chlamydia or tuberculosis), and in rare cases by Young's syndrome or Kartagener's syndrome [90]. Obstructions can also be acquired by vasectomy or iatrogenic injuries. In men with obstructive azoospermia their testicular histology is normal. Endocrinological investigation usually shows normal follicle stimulating and luteinising hormone levels and a normal karyotype. This is in contrast to those men with non-obstructive azoospermia whose hormone levels are elevated and whose testes are often small with a soft consistency. Non obstructive azoospermia is associated with spermatogenic impairment. This may be manifested in maturation arrest or by a complete absence of sperm in the seminiferous tubules, Sertoli cell only syndrome.

\section{THE MANAGEMENT OF MEN WITH OBSTRUCTIVE AZOOSPERMIA}

Azoospermia is determined by two semen analyses where no sperm are observed. This is followed by an examination of the patient together with history, endocrine profile and karyotyping. Until recently it has been accepted that normal levels of $\mathrm{FSH}$ and $\mathrm{LH}$ are predictive of the presence of sperm in the seminiferous tubules [73]. Inhibin $B$ has also be suggested as a useful predictor [7]. However more recent reports $[22,34,50]$ have reported their poor predicti- ve value. The predictive value of testicular histology has more support with positive correlations with successful gamete retrieval in numerous studies $[89,78,74,79]$.

A diagnostic biopsy (see range of methods below) will be performed before the female partner begins her ovulation stimulation regime. Any histopathology in the biopsy will be determined and sperm will be frozen and thawed to determine their susceptibility to cryo-injury. If suitable, a treatment biopsy will be performed, either on the day of ooctye retrieval if fresh sperm are to be used or prior to that day if frozen sperm are to be utilized.

\section{SPERM RETRIEVAL TECHNIQUES}

The first technique employed for sperm retrieval was microsurgical epididymal sperm aspiration (MESA) by TempleSmith et al. in 1985 [88].

This is an invasive procedure involving opening the scrotum to investigate epididymis and testes. As such it requires theatre time and a team of trained staff making it a demanding and expensive task. Although this was still an option a decade later when Devroey et al., [23] reported their open testicular biopsy TESE technique, sperm retrieval was rapidly simplified to less invasive percutaneous epididymal sperm aspirations (PESA) by Craft et al., [17] or fine needle testicular sperm aspirations (TESA) by Craft and Tsirigotis [18]. In these, sperm are retrieved under local anaesthetic in technically less demanding, less traumatic outpatient procedures. However, Tournaye et al. have reported [89] that the main limitation of these techniques was that the total number of sperm retrieved were significantly lower than from open biopsy.

In our centre [83] we modified the TESA technique using a larger guage needle (14 guage) to allow an increased number of sperm to be retrieved in an attempt to retrieve all the sperm required for male's future reproductive needs from one biopsy.

\section{LONG TERM EFFECTS OF BIOPSIES}

Several studies examining gross testicular parameters following biopsies have shown no damage. Our group [84] assessed the post biopsy status of the testis in terms of hematomas and scars by postbiopsy testicular ultrasound, serum antisperm antibodies and pituitary gonadotrophins and testosterone levels and found no significant differences. Similarly, Schill et al., [72] found no alterations in endocrine function or testicular size (assessed by Doppler scrotal sonography). In contrast, Ramasamy et al., [67] found a significant decrease in testosterone three to six months after TESE surgery with concomitant increases in follicle stimulating hormone and luteinizing hormones. Pathological consequences of biopsying have also been reported by Schlegel et al. [73] with a high incidence of both inflammation and haematomas and also devascularization in a small number of patients. Animal studies have allowed more detailed investigations of the impact of repeated testicular aspirations. Even these less invasive 'fine needle' methods of sperm retrieval have been shown to cause 'severe, pro- 
gressive and irreversible damage on the architecture of the tubules in the needle's path' [76]. This group also reported that the degree of damage increased with repeated procedures. They [76] also shown that TESE causes localized scarring and fibrosis. This may account for evidence that scarring from previous biopsies impairs the retrieval of sperm in subsequent attempts [63].

\section{FOLLOW UP OF BABIES CONCEIVED BY ICSI}

Since the choice of a sperm for ICSI is arbitrary, in fact often using immature sperm which Nature would reject, there have been concerns as to the safety of ICSI and the health of children conceived in this way. Initial data [13] albeit conflicting [11], suggested that the mental development of ICSI babies was slower. The differences between these studies may be due to insufficient numbers or confounding factors such as differing socio-economic groups. Major and minor congenital anomalies [44] were also reported to be more prevalent in ICSI babies than in the general population. However, in a large comparative study in 2000 Wennerholm et al., [101] compared ICSI births with IVF births and found no increase in major malformations between these two groups, concluding that this increased rate of congenital malformations is not associated with sperm origin or quality but rather due to a higher rate of multiple births. In 1998, the European Society Human Fertilization and Embryology ICSI Task Force confirmed the findings of smaller studies, reporting an increased risk $(2 \%)$ of chromosomal abnormalities in ICSI babies [87].

The next major study was conducted by the International collaborative study of ICSI child and family outcomes group over a five year period [87] and no differences in cognitive, neurological or socio-economic development were observed although they highlighted an increase in urogenital problems in males more recently. In 2004 a meta-analysis [68] found compared major malformations rates ranged from $1.1-9.7 \%$ in ICSI compared with $0-6.9 \%$ in spontaneously conceived infants. However they stressed that some of the studies had inappropriate control groups, including infertile patients who had then conceived without treatment and suggested that this increased the rate of malformations in the controls. Most recently, a systematic review of all the papers with data relating to birth defects in infants following ICSI and or IVF compared with spontaneously conceived infants was published [35] where the results of the metaanalysis suggested a dramatic $30-40 \%$ increase of birth defects associated with ART. This latest paper has led to renewed interest and active debate.

\section{COMPARISON OF SUCCESS RATES FOR AZOOSPERMIA OF DIFFERING AETIOLOGIES}

The cause of a man's azoospermia has an influence on the couples' ICSI outcome. Again, meta-analyses have played a major role in drawing together our knowledge to date. Significantly higher fertilization rates and clinical pregnancy rates have been reported in men with obstructive azoospermia compared with those who presented with non obstructive azoospermia [57]. These findings are supported by those from a large retrospective analysis of $911 \mathrm{ICSI}$ cycles [96]. Several studies have reported this trend of lower success outcomes culminating with lower live birth rates and increased miscarriages [31, 94]. However, again the metaanalysis previously cited [57] concludes for those couples achieving a pregnancy there was no difference in ongoing pregnancy rates or miscarriage rates. Further, Vernaeve et al. [96] have reported non significant differences in multiple births, preterm deliveries and low birth weights.

\section{THE IMPORTANCE OF SPERM NUCLEAR AND MITOCHONDRIAL DNA ON ASSISTED REPRODUCTIVE OUTCOME}

Male fertility potential for assisted reproduction by ICSI cannot be measured by conventional parameters. Sperm nuclear DNA (nDNA) integrity is increasingly recognised as a useful indicator of male fertility potential. Sperm with nDNA damage above a certain threshold are associated with a longer time to conceive in otherwise apparently fertile couples [28, 80] and a higher miscarriage rate [28]. Infertile men have also been shown to have more nDNA anomalies than sperm donors and fertile men [70, 39, 102]. These defects include poor DNA packaging $[70,30]$ increased strand breaks $[49,39]$ greater susceptibility to DNA denaturation [28] and a higher incidence of chromosomal abnormalities [54]. In ICSI cycles, DNA damage has been shown to be associated with impaired embryo cleavage [55]. In addition, higher rates of pregnancy loss have been documented in ICSI than in IVF [8]. As these pregnancies were almost inevitably achieved with sperm of poor quality that would have been incapable of fertilising an oocyte naturally, there may well be a link with sperm nDNA damage. Yet, because of the success of ICSI in bypassing rather than addressing the problem of poor sperm quality, such defective sperm are being used indiscriminately in clinical treatments.

The nucleus is not the sperm's only source of DNA. The mitochondrion also has its own genome. During recent years, mtDNA mutations have been identified in numerous diseases [98]. Mitochondrial DNA changes have also been identified as the origin of ageing [75] and more recently as a cause of male infertility $[19,81]$. Mitochondrial DNA is also an indicator of the health of the sperm. Mitochondrial DNA deletions lead to deficient OXPHOS that, in turn, causes abnormal metabolism and inadequate sperm motility. We recently studied the relationship between testicular sperm mitochondrial $(\mathrm{mt})$ DNA deletions, nuclear $(\mathrm{n})$ DNA fragmentation from 28 men with obstructive azoospermia undergoing ICSI and their partners' fertilisation and pregnancy rates after ICSI. The testicular sperm were retrieved using a 14 guage Trucut needle. MtDNA analysed using a long polymerase chain reaction and an alkaline Comet assay was used to determine nDNA fragmentation. Of subjects who achieved a pregnancy $(50 \%)$ using testicular sperm, only $26 \%$ had partners' sperm with wild type (WT) mtDNA. Further, the successful group had less mtDNA deletions and less nDNA fragmentation. There were inverse relationships between pregnancy and mtDNA deletion num- 
bers, size and nDNA fragmentation for both testicular and ejaculated sperm (Table 1). No relationships were observed with fertilisation rates. We combined the data about DNA quality from both sources within sperm to provide a potentially valuable prognostic test. The information was incorporated into a simple scoring system for clinicians to use to counsel patients more appropriately (Figure 1). For the first time, by using this algorithm the clinician will be able to give couples a more quantitative estimate of their chances of a pregnancy from their treatment.

\section{TESTICULAR SPERM VULNERABILITIES}

Testicular sperm DNA. Sperm chromatin differs from somatic cells in structure and composition. During spermiogenesis the majority of histones are replaced with small, highly basic protamines [64] that are half the size of histones [29] and organized into unique supercoiled doughnuts, called toroids [99]. During transit through the epididymis, the protamines crosslink by forming disulphide bonds and this process compresses sperm DNA into one sixth the volume occupied by somatic cell nuclei [29]. This highly cross-linked structure affords a measure of protection to sperm DNA and to some extent compensates these cells for their impaired DNA repair capacity. Thus, testicular sperm, in which this process have not been completed, appear to be more susceptible to DNA damage than ejaculated sperm $[47,33,5]$.

\section{CRYOINJURY AND TESTICULAR SPERM CULTURE}

Analysis of incubation effects on testicular sperm DNA is also extremely relevant since this is now routine clinical practice [48]. The selection of ejaculated sperm for ICSI involves the evaluation of motility, as this gives an indication of the viability of the sperm [58]. The selection of viable testicular sperm for ICSI can be difficult due to lack of inherent motility and the choice of a nonviable sperm may lead to lower fertilisation rates than obtained with ejaculated sperm [26]. Cryopreservation of testicular sperm ensures the availability of sperm for subsequent treatment cycles without the need to perform additional biopsies [77].

The technique of culturing testicular sperm in vitro prior to ICSI has been recommended by a number of groups $[48,6$, $37,27]$ in order to promote an increase in sperm motility. A period of 24 hours has been suggested as optimal for the development of motility in a sufficient number of testicular sperm to give choice in the treatment cycle [37]. However, the process of freeze-thawing has been found to significantly decrease the vitality of testicular sperm immediately post-thaw [95]. Ultrastructural cryoinjuries have also been observed in thawed testicular sperm in the form of rupturing of the plasma and acrosomal membranes [59]. The use of simulated maturation of testicular sperm in vitro assumes that it has only positive effects. Very often culturing in vitro takes place in simple, unsupplemented media $[48,6,37]$ or media which is not changed or gassed with $\mathrm{CO}_{2}$ for up to 7 days [26]. This may lead to a lack of energy substrates for the sperm as they develop motility and also a change in $\mathrm{pH}$ in the culture media.

Oxidative stress and ROS production have been shown to increase during incubation of ejaculated sperm and indeed to peak at 24 hours [15]. Sperm produce low levels of ROS naturally as by-products of the electron transfer chain, however, these may accumulate during culture and gradually become toxic to the sperm [2]. Testicular sperm are more susceptible as they produce more ROS, possessing residual cytoplasm prior to transit through the epididymis [32].

Retained cytoplasm in immature sperm has high levels of nicotinamide adenine dinucleotide phosphate (NADPH) oxidase [3], which acts as a substrate in the generation of superoxide $\left(\mathrm{O}_{2}{ }^{-}\right)$, which causes lipid peroxidation and DNA damage [92]. However, the amount of cytoplasm is not enough to afford them antioxidant protection [4]. Culture of

Table 1 : Relationships between fragmented DNA in fresh, frozen-thawed and post-cryopreservation incubated testicular sperm. From Lewis et al. [47].

\begin{tabular}{lccccc}
\hline $\begin{array}{l}\text { Sperm } \\
\text { Source }\end{array}$ & $\mathbf{n}$ & $\begin{array}{c}\text { ISCITISCI } \\
\text { Outcome }\end{array}$ & $\begin{array}{c}\text { nDNA } \\
\text { fragmentation } \\
(\%)\end{array}$ & $\begin{array}{c}\text { mtDNA } \\
\text { deletion } \\
\text { number }\end{array}$ & $\begin{array}{c}\text { mtDNA } \\
\text { deletion } \\
\text { size (kb) }\end{array}$ \\
\hline Testicular & 14 & Pregnant & $16.1 \pm 1.7$ & $1.29 \pm 0.29$ & $3.08 \pm 0.52$ \\
Testicular & 14 & Not Pregnant & $26.4 \pm 3.1^{*}$ & $2.86 \pm 0.35^{\star}$ & $5.91 \pm 0.41^{*}$ \\
Ejaculated & 26 & Pregnant & $21.4 \pm 2.1^{\dagger}$ & $2.43 \pm 0.29^{\dagger}$ & $3.90 \pm 0.30^{\dagger}$ \\
Ejaculated & 41 & Not Pregnant & $27.4 \pm 1.5^{\star}$ & $3.29 \pm 0.22^{\star}$ & $4.69 \pm 0.27^{\star}$ \\
\hline
\end{tabular}

Values are means \pm S.E.

* $\quad P<0.05$ significant differences between successful and unsuccessful outcome with testicular or ejaculated sperm.

$t \quad P<0.05$ significant differences between testicular and ejaculated sperm. 


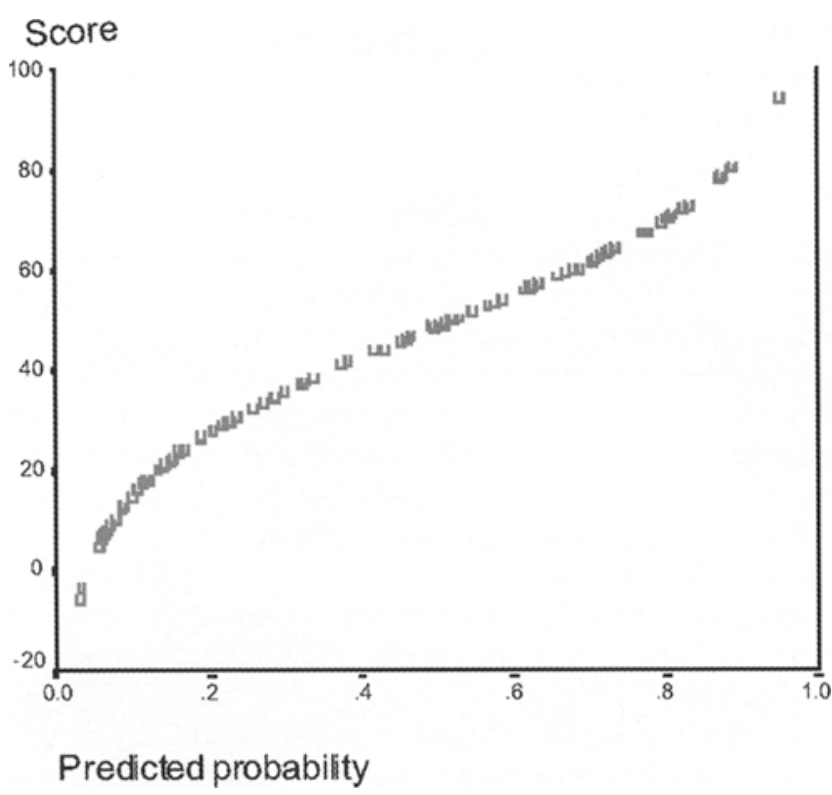

Figure 1 : Graphical description of probability. From Lewis et al. [47]. A plot of prognostic score against predicted probabilities from the regression model showing linearity over a broad range of probabilities. For example, a prognostic score of 84 gives a probability of pregnancy of $91 \%$, a prognostic score of 47 gives a probability of pregnancy of $47 \%$ and a prognostic score of 3 gives a probability of pregnancy of only $5 \%$.

testicular sperm to facilitate motility acquisition [58] may lead to an accumulation of $\mathrm{ROS}, \mathrm{O}_{2}{ }^{-}$and hydrogen peroxide $\left(\mathrm{H}_{2} \mathrm{O}_{2}\right)$, which could overwhelm the sperm antioxidant defence. $\mathrm{H}_{2} \mathrm{O}_{2}$ is not intrinsically toxic to sperm but it inactivates a ROS scavenging system instead, making sperm susceptible to gradual oxidative DNA damage from ROS [42]. Additionally, the accumulation of ROS may be released into the culture medium, which contains no antioxidant protection, allowing further damage to sperm plasma membranes.

Production of $\mathrm{O}_{2-}^{-}$has also been found to increase during the cooling process for freezing sperm and to a greater extent in the freeze-thawing process in bovine ejaculated sperm [16]. In the same study it was noted that $\mathrm{H}_{2} \mathrm{O}_{2}$ did not significantly increase and suggested that the $\mathrm{O}_{2}-$ anion was not generating $\mathrm{H}_{2} \mathrm{O}_{2}$ but causing oxidative damage to cellular structures. This may provide a reason why the DNA damage observed in this study is greater immediately after thawing than in fresh sperm, and why incubation of testicular sperm post-cryopreservation causes greater damage to the DNA $(30.4 \%)$ than incubation of fresh testicular sperm $(19.1 \%)$. ROS acting on DNA during the cooling period before freezing and during thawing may predispose the DNA to further damage during post-thaw incubation. The use of antioxidants supplements in media during incubation may reduce free radicals and oxidants [97].
Work from our laboratory [25] has shown that mature sperm DNA from infertile men is damaged by freeze-thawing, while in fertile men, the DNA is unaffected. In contrast, cryoinjury is observed similarly in testicular sperm from fertile and infertile men. This may be due to the fact that all testicular sperm are more vulnerable to oxidative damage than ejaculated sperm since their DNA is not yet crosslinked for protection although having completed spermiogenesis, transcription and translation and therefore the ability to repair, is switched off [4].

Cryopreservation has been found to have a detrimental effect on the viability [66] and morphology of testicular and ejaculated sperm $[95,60]$ due to the formation of intracellular ice, which causes the rupturing of plasma membranes [53]. Another group detected swelling and rupturing of the acrosomal and plasma membranes after freeze-thawing, also in testicular sperm [59]. These morphological alterations, which occur during cryopreservation, may lead to the increased vulnerability of testicular sperm demonstrated in this study, due to plasma membrane damage allowing ROS to access sperm nuclei and adversely affect DNA integrity during incubation. Testicular sperm morphology was found to be comparable between fertile and infertile men [82] without cryopreservation. This may also explain why testicular sperm DNA from fertile men are no better at withstanding the freezing process than those from obstructive azoospermic men.

Incubation of fresh testicular sperm appears to be beneficial only in terms of motility and morphology development and in the selection of the best viable sperm for ICSI. However, incubation of fresh and frozen-thawed testicular sperm is clearly damaging to nuclear DNA (Table 2). Our study [20] provided compelling evidence that fresh and frozen-thawed testicular sperm should be injected without delay in order to protect the genetic health of the resulting child. As even sperm with damaged DNA can fertilise oocytes during ICSI [93], it is vital that steps be taken to protect the sperm DNA and consequently lower the risk of passing damaged genetic information to the offspring.

\section{POST VASECTOMY TESTICULAR SPERM YIELDS}

Each year 40,000 men in the UK have a vasectomy. Traditionally, vasectomy was considered an irreversible form of contraception. However, increasingly men are requesting reversal to have a second family and now 2400 $(\sim 6 \%)$ men request reversal [65]. Even when surgery is successful, anti-sperm antibodies impair sperm function in up to $50 \%$ of cases thus reducing fertility. In addition, Kolettis et al. [41] found that vasectomy reversal is associated with seminal oxidative stress which can impair sperm structure [38] and function [21]. There is evidence that men who have had a vasectomy for less than $2 y r s$ have a $50 \%$ chance of a pregnancy whereas those whose male partners had their vasectomy more than $15 y$ rs previously have a $30 \%$ chance of a spontaneous pregnancy [51]. Since these were previously fertile men it has been assumed that they had 'fertile' sperm. However, as yet, the long term consequences of 
Table 2 : Relationships between fragmented DNA in fresh, frozen-thawed and post-cryopreservation incubated testicular sperm. From Dalzell et al. [20].

\begin{tabular}{|c|c|c|c|}
\hline Group & $\begin{array}{l}\text { Time point of } \\
\text { analysis }\end{array}$ & $\begin{array}{c}\text { DNA } \\
\text { fragmentation } \% \\
\text { mean } \pm \text { S.E. }\end{array}$ & $\mathbf{P}$ \\
\hline \multirow{3}{*}{$\begin{array}{l}\text { Fertile } \\
n=18\end{array}$} & Fresh & $9.4 \pm 0.65$ & - \\
\hline & Frozen-thawed & $15.5 \pm 1.16$ & 0.013 \\
\hline & $24 \mathrm{hr}$ post-thaw & $18.5 \pm 1.58$ & 0.007 \\
\hline \multirow{6}{*}{$\begin{array}{l}\text { Infertile } \\
n=34\end{array}$} & Fresh & $10.6 \pm 1.02$ & - \\
\hline & $4 \mathrm{hr}$ & $22.1 \pm 3.49$ & 0.052 \\
\hline & $24 \mathrm{hr}$ & $19.1 \pm 2.33$ & 0.017 \\
\hline & Frozen-thawed & $16.5 \pm 1.00$ & 0.0001 \\
\hline & $4 \mathrm{hr}$ post-thaw & $29.5 \pm 1.45$ & 0.00004 \\
\hline & $24 \mathrm{hr}$ post-thaw & $30.4 \pm 1.71$ & $<0.00001^{a}$ \\
\hline
\end{tabular}

Note : $\mathrm{P}$ values are comparisons to fresh data in each group.

a Difference between fertile and infertile groups, $p=0.00001$.

vasectomy on testicular, sperm function or future fertility have not been well documented.

For men wishing to have second families post-vasectomy, vasectomy reversal, since 1995, has been replaced in part by testicular biopsy via fine-needle testicular sperm aspiration (TESA) or percutaneous epididymal sperm aspiration (PESA) performed at an outpatient clinic and subsequently. Sperm obtained can then be used in ICSI.

We determined the effects of vasectomy on sperm yield and testicular histology. Secondly, we aimed to compare the fertility outcomes (cumulative embryo score and clinical pregnancy rates) after assisted conception of normal female partners of vasectomised men and men with obstructive azoopsermia (OA) [52].

Sperm yields/g of testis were significantly decreased in men vasectomised 5-9 yrs and $\geq 10 y r s$ previously and also in obstructive azoospermic men of other aetiologies, relative to fertile men (Table 3). A significant reduction was also observed in the number of early $(40 \%, p<0.005)$ and mature $(29 \%, p<0.05)$ spermatids, and an increase of $31 \%$ was seen in the thickness of the seminiferous tubule wall (basal membrane and collagen) of vasectomised men $\geq 10 \mathrm{yrs}$ relative to fertile men. There was a significant reduction in the clinical pregnancy rates in the partners of men who had had a vasectomy $\geq 10 y$ rs previously (Table 3 ).

\section{POST-VASECTOMY PREGNANCY RATES}

We also assessed the clinical pregnancy rate of the partners of men who have undergone a vasectomy using TESA
Table 3 : Effects of vasectomy on sperm yield. From McVicar et al. [52].

\begin{tabular}{lcccc}
\hline & $\begin{array}{c}\text { Group 1 } \\
\text { Vas 5-9yrs } \\
n=12\end{array}$ & $\begin{array}{c}\text { Group 2 } \\
\text { Vas } \geq 10 y r s \\
n=12\end{array}$ & $\begin{array}{c}\text { Group 3 } \\
\text { OA } \\
n=32\end{array}$ & $\begin{array}{c}\text { Group 4 } \\
\text { Fertile } \\
n=39\end{array}$ \\
\hline $\begin{array}{l}\text { Sperm } \\
\text { yield }\end{array}$ & $3.61 \pm$ & $3.79 \pm$ & $3.00 \pm$ & $11.18 \pm$ \\
$\times 106 / g$ & $1.26 *$ & $1.06 *$ & $0.43 *$ & 1.56 \\
\pm SEM & & & & \\
\hline
\end{tabular}

${ }^{\star} p=0.000$ each compared with Group 4.

followed by ICSI. We found a significant reduction (28 to $9 \%$ ) in the clinical pregnancy rate of the partners of the men who have had a vasectomy $\geq 10 y$ rs relative to those of men with $O A$ from other aetiologies. Our work confirms that of Abdelmassih et al. [1] who have recently reported a negative correlation between pregnancy rates after ICSI using epididymal sperm and an increasing time interval after vasectomy. This is also supported by Borges et al. [10,12] who used sperm retrieved from the epididymis followed by ICSI after vasectomies $14 \mathrm{yrs}$ previously. They reported an increase in miscarriage rates. Further, Kubota [43] reported degenerative changes in the spermatids and sperm of vasectomised men. All these studies suggest that the quality of post-vasectomy sperm may be compromised and that they are less capable of achieving a pregnancy.

\section{APOPTOSIS AND POST-VASECTOMY SPERM YIELDS}

We sought to determine a mechanism by which this reduction in sperm yield and pregnancy rate was effected by investigating the incidence of apoptosis in the seminiferous tubules (Figure 2) [62]. In general, apoptosis plays an important role in the testis $[45,69]$ by eliminating $50-70 \%$ of germ cells at different stages of spermatogenesis prior to spermiogenesis $[40,9,61]$. This results in the maintenance of the maximum number of cells that can be optimally supported by the fixed population of Sertoli cells under the changing conditions of the testis as for example during stress or infection $[71,14]$. The key initiator of testicular apoptosis is believed to be the Fas/FasL pathway [45, 46]. It is then regulated by many protein interactions, including those of the Bcl-2 family, before the cells commit to the process via caspases and later endonuclease activation. Caspase 3 is the main executor of this irreversible apoptotic cascade [100].

We observed increased intensities of FasL and Bax staining in the seminiferous tubules in vasectomised men. FasL positivity (\%) also increased in Sertoli cells, and both FasL and Fas positivity (\%) increased in primary spermatocytes and round spermatids of vasectomised men. Sperm DNA fragmentation, an end point marker of apoptosis, increased significantly in vasectomised men compared to fertile men. 


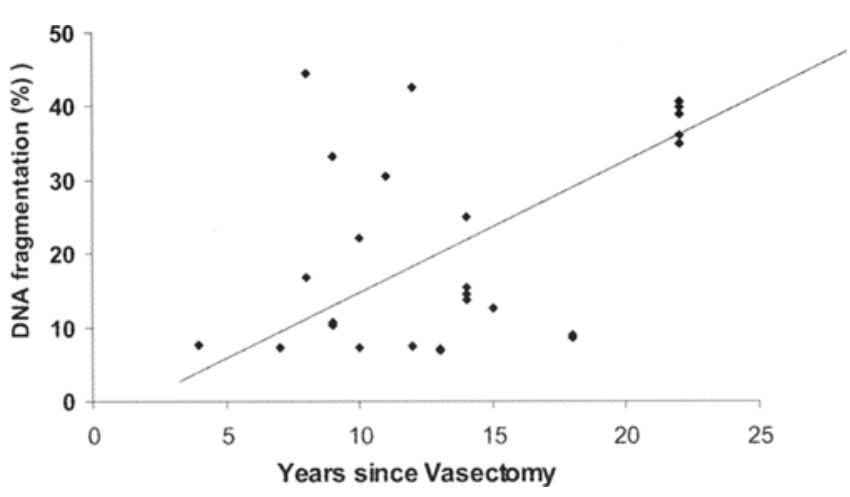

Figure 2 : Correlation between DNA fragmentation and years since vasectomy. From O'Neill et al., 2006 [62] (provisional acceptance).

We concluded that reduced sperm yields post-vasectomy were associated with increased apoptosis via the Fas-FasL and Bax pathways with the remaining sperm displaying increased DNA fragmentation.

\section{POST-VASECTOMY TESTICULAR SPERM QUALITY}

The elevated sperm DNA damage increasing with time observed by us (Figure 2) is supported by Steger et al., [86] who reported a post-vasectomy alteration of sperm nuclear chromatin condensation as a result of delayed protamine expression. Histone-protamine exchange is known to play an important role in the protection of sperm DNA by compaction and is essential for the maturation of healthy sperm. Steger's group also observed spermatogenic arrest at the round spermatid stage in association with delayed expression of protamine transcripts. This DNA fragmentation may be an indication of the irreversible late stage execution of apoptosis. It also gives us a possible explanation of the reduction in the clinical pregnancy rate in the partners of the vasectomized men recently reported by us [52]. Our work is in agreement with Abdelmassih et al. [1], who recently reported a negative correlation between pregnancy rates after ICSI using epididymal sperm and an increasing time interval after vasectomy although in conflict with Nicopoullos et al., [56] who found that maternal age, and not the interval since vasectomy was the principal determinant of ICSI success. Also in support is a study by Borges et al. [10] who used sperm retrieved from the epididymis followed by ICSI after vasectomies 14 yrs previously. In addition, they reported an increase in miscarriage rates. All these studies suggest that the quality as well the quantity of post-vasectomy sperm may be compromised and that they are less capable of achieving a pregnancy. Men seeking vasectomies and infertility specialists should be made aware of these long term effects and their implications for future infertility treatment for this group of patients.

\section{CONCLUSION}

Treatments for azoospermic men have been advanced enormously by the introduction of ICSI and its facility to use immature sperm. Assisted conception success rates are now as high using these sperm as with ejaculated sperm. However, there appears to be a hesitance to apply our ever expanding knowledge of testicular sperm characteristics to best clinical practice. If, in the future, clinicians and scientists work more closely, there will be the opportunity to improve success rates and benefit more patients in this exciting area of andrology.

\section{REFERENCES}

1. ABDELMASSIH V., BALMACEDA J., TESARIK J., ABDELMASSIH R., NAGY N. : Relationship between time period after vasectomy and the reproductive capacity of sperm obtained by epidymal aspiration. Hum. Reprod., 2002, 17 : 736-740.

2. AITKEN R.J. : Free radicals, lipid peroxidation and sperm function. Reprod. Fertil. Dev., 1995, 7 : 659-668.

3. AITKEN R.J., FISHER H.M., FULTON N. et al. : Reactive oxygen species generation by human spermatozoa is induced by exogenous NADPH and inhibited by the flavoprotein inhibitors diphenylene iodonium and quinacrine. Mol. Reprod. Dev., 1997, $47: 468-482$.

4 AITKEN R.J., GORDON E., HARKISS D. et al. : Relative impact of oxidative stress on the functional competence and genomic integrity of human spermatozoa. Biol. Reprod., 1998, $59: 1037-1046$.

5. ALVAREZ J.G. : Efficient treatment of infertility due to sperm DNA damage by ICSI with testicular sperm. Hum. Reprod., 2005, $20: 2031-2032$.

6. BALABAN B., URMAN B., SERTAC A. et al. : In vitro culture of spermatozoa induces motility and increases implantation and pregnancy rates after testicular sperm extraction and intracytoplasmic sperm injection. Hum. Reprod., 1999, 14 : 28082811.

7. BALLESCA J.L., BALASCH B., CALAFELL J.M. et al. : Serum inhibin $B$ determination is predictive of successful testicular sperm extraction in men with non-obstructive azoospermia. Hum. Reprod., 2000, 15 : 1734-1738.

8. BAR-HAVA I., ASHKENAZI J., SHELEF M. et al. : Morphology and clinical outcomes of embryos after in vitro fertilization are superior to those after intracytoplasmic sperm injection. Fertil. Steril., 1997, 68 : 653-657.

9. BILLIG H., FURUTA I., RIVIER C., TAPANAINEN J., PARVINEN M., HSUEH A.J. : Apoptosis in testis germ cells : Developmental changes in gonadotropin dependence and localisation to selective tubules stages. Endocrinology, 1995, $136: 5-12$.

10. BORGES E.J., ROSSI-FERRAGUT L.M., PASQUALOTTO F.F. et al. : Testicular sperm results in elevated miscarriage rates compared to epididymal sperm in azoospermic patients. Sao Paulo Med. J., 2002, $120: 122-126$.

11. BONDUELLE M., LIEBAERS I., DEKETELAERE V. : Neonatal data on a cohort of 2889 infants born after ICSI (1991-1999) and of 2995 infants born after IVF (1983-1999). Hum. Reprod., 2002, $17: 671-694$.

12. BORGES E., ROSSI-FERRAGUT L., PASQUALOTTO F., ROCHAC., IACONELLI A. : Different intervals between vasectomy and sperm retrieval interfere in the reproductive capacity from vasectomised men. J. Assist. Reprod. Genet., 2003, 20 : 33-37. 
13. BOWEN J.R., GIBSON F.L., LESLIE G.I., SAUNDERS D.M. : Medical and developmental outcome at 1 year for children conceived by intrscytoplasmic sperm injection. Lancet, 1998, 351 : 1529-1534.

14. BRAUN R.E. : Early sperm is scared or is it ? Nature Genet., 1998, $18: 202-204$

15. CALAMERA J.C., FERNANDEZ P.J., BUFFONE M.G., ACOSTAA.A., DONCEL G.F. : Effects of long term in vitro incubation of human spermatozoa : functional parameters and catalase effect. Andrologia, 2001, $33: 79-86$.

16. CHATTERJEE S., GAGNON C. : Production of reactive oxygen species by spermatozoa undergoing cooling, freezing and thawing. Mol. Reprod. Dev., 2001, 59 : 451-458.

17. CRAFT I., TSIRIGOTIS M., BENNETT V. et al. : Percutaneous epididymal sperm aspiration and intracytoplasmic sperm injection in the management of infertility due to obstructive azoospermia. Fertil. Steril., 1995, 63 : 1038-1042.

18. CRAFT I., TSIRIGOTIS M. : Simplified recovery, preparation and cryopreservation of testicular spermatozoa. Hum. Reprod., 1995, $10: 1623-1627$.

19. CUMMINS J.M., JEQUIER A.M., KAN R. : Molecular biology of human male infertility : links with aging, mitochondrial genetics and oxidative stress ? Mol. Reprod. Dev., 1994, 37 : 345-362.

20. DALZELL L.H., THOMPSON-CREE M.E.M., McCLURE N., TRAUB A.I., LEWIS S.E.M. : The effects of 24-hour incubation after freeze-thawing on DNA fragmentation of testicular sperm from infertile and fertile men. Fert. Steril., 2003, 79:16701672.

21. DE LAMIRANDE E., TSAI C., HARAKAT A., GAGNON C. Involvement of reactive oxygen species in human sperm acrosome reaction induced by $\mathrm{A} 23187$, lysophosphatidylcholine, and biological fluid ultrafiltrates. J. Androl., 1998, $19: 585-594$.

22. DEVOTO E., MADARIAGA M., LIOI X. : Causes of male infertility. The contribution of the endocrine factor. Rev. Med. Chil., 2000, $128: 184-192$.

23. DEVROEY P., LIU J., SILBER S., NAGY Z., VAN STEIRTEGHEM A.C. : Normal fertilisation of human oocytes after testicular sperm extraction and intracytoplasmic sperm injection. Fertil. Steril., 1994, 62 : 639-641.

24. DEVROEY P., LIU J., NAGY Z., et al. : Pregnancies after testicular sperm extraction and intracytoplasmic sperm injection in non-obstructive azoospermia. Hum. Reprod., 1995, 10 : 14571460.

25. DONNELLY E.T., STEELE E.K., MCCLURE N., LEWIS S.E.M.: Assessment of DNA integrity and morphology of ejaculated spermatozoa from fertile and infertile men before and after cryopreservation. Hum. Reprod., 2001,16 : 1191-1199.

26. EDIRISINGHE W.R., JUNK S.M., MATSON P.L., YOVICH J.L.: Changes in motility patterns during in-vitro culture of fresh and frozen/thawed testicular and epididymal spermatozoa : implications for planning treatment by intracytoplasmic sperm injection. Hum. Reprod., 1996, 11 : 2474-2746.

27. EMILIANI S., VAN DEN BERGH M., VANNIN A.-S., BIRAMANE J., VERDOODT M., ENGLERT Y. : Increased sperm motility after in vitro culture of testicular biopsies from obstructive azoospermic patients results in better post-thaw recovery rate. Hum. Reprod., 2000, $15: 2371-2374$.

28. EVENSON D. P., JOST L.K., MARSHALL D. et al. : Utility of the sperm chromatin structure assay as a diagnostic and prognostic tool in the human fertility clinic. Hum. Reprod., 1999, 14 : 1039-1049.

29. FUENTES-MASCORRO G., SERRANO H., ROSADO A. Sperm chromatin. Arch. Androl., 2000, 45 : 215-225.
30. FILATOV M.V., SEMENOVA E.V., VOROB'EVA O.A., LEONT'EVA O.A., DROBCHENKO E.A. : Relationship between abnormal sperm chromatin packing and IVF results. Mol. Hum. Reprod., 1999, $5: 825-830$.

31. GHAZZAWI I.M., SARRAF M.G., TAHER M.R., KHALIFA F.A.: Comparison of the fertilizing capacity of spermatozoa from ejaculates, epididymal aspirates and testicular biopsies using intracytoplasmic sperm injection. Hum. Reprod., 1998, 13 : 348-352.

32. GIL-GUZMAN E., OLLERO M., LOPEZ M.C. et al. : Differential production of reactive oxygen species by subsets of human spermatzoa at different stages of maturation. Hum. Reprod., 2001, 16 : 1922-1930.

33. GRECO E., ROMANO S., LACOBELLI M, et al. : ICSI in cases of sperm DNA damage : beneficial effect of oral antioxidant treatment. Hum. Reprod., 2005, 20 : 2590-2594.

34. HALDER A., FAUZDAR., KUMAR A. : Serum inhibin B and follicle-stimulating hormone levels as markers in the evaluation of azoospermic men : a comparison. Andrologia, 2005, 37 : 173179.

35. HANSEN M., BOWER C., MILNE E., DE KLERK N., KURINCZUK J.J. : Assisted reproductive technologies and the riks of birth defects - a systematic review. Hum. Reprod., 2005, 20 : 228-338.

36. HOVATTA O., MOILANEN J., VON SMITTEN K., REIMA I. : Testicular needle biopsy, open biopsy epididymal aspiration and intracytoplasmic sperm injection in obstructive azoospermia. Hum. Reprod., 1995, $10: 2595-2599$.

37. HU Y., MAXSON W.S., HOFFMAN D.I., ORY S.J., LICHT M.R., EAGER S. : Clinical application of intracytoplasmic sperm injection using in vitro cultured testicular spermatozoa obtained the day before egg retrieval. Fertil. Steril., 1999, 72 : 666-669.

38. HUGHES C., LEWIS S., MCKELVEY-MARTIN V., THOMPSON W. : The effects of antioxidant supplementation during Percoll preparation on human sperm DNA integrity. Hum. Reprod., 1998, 13 : 1240-1247.

39. IRVINE D.S., TWIGG J.P., GORDON E.L., FULTON N., MILNE P.A., AITKEN R.J. : DNA integrity in human spermatozoa : relationships with semen quality. J. Androl., 2000, 21 : 33-44.

40. JOHNSON L., PETTY C.S., PORTER J.C., NEAVES W.B. : Germ cell degeneration during postprophase of meiosis and serum concentrations of gonadotropins in young adult and older adult men. Biol. Reprod., 1984, 31 : 779-784.

41. KOLETTIS P., SHARMA R., PASQUALOTTO F., NELSON D., THOMAS A., AGARWAL A. : Effect of seminal oxidative stress on fertility after vasectomy. Fertil. Steril., 1999, $71: 249-255$.

42. KRZYZOSIAK J., EVENSON D., PITT C., JOST L., MOLAN P., VISHWANATH R. : Changes in susceptibility of bovine sperm to in situ DNA denaturation during prolonged incubation at ambient temperature under conditions of exposure to reactive oxygen species and nuclease inhibitor. Reprod. Fertil. Dev., 2000, $12:$ : 251-261.

43. KUBOTA R. : Electron microscopic study on the testis after vasectomy in rats and men. Jap. J. Urol., 1969, $60: 373-397$.

44. KURINCZUK J.J., BOWER C. : Birth defects in infants conceived by intracytoplasmic sperm injection : an alternative interpretation. Brit. Med. J., 1997, 315 (7118) : 1260-1265.

45. LEE J., RICHBURG J.H., YOUNKIN S.C., BOEKELHEIDE K. : The fas system is a key regulator of germ cell apoptosis in the testis. Endocrinology, 1997, $138: 2081-2088$.

46. LEE J., RICHBURG J.H., SHIPP E.B., MEISTRICH M.L., BOEKELHEIDE K. : The Fas system, a regulator of testicular 
germ cell apoptosis, is differentially up-regulated in sertoli cell versus germ cell injury of the testis. Endocrinology, 1999, 140: 852-858.

47. LEWIS S.E.M., O'CONNELL M., STEVENSON M., MCCLURE $\mathrm{N}$. : An algorithm to predict pregnancy in assisted reproduction. Hum. Reprod., 2004, $19:$ 1385-1394.

48. LIU J., TSAI Y.-L., KATZ E., COMPTON G., GARCIA J.E., BARAMKI T.A. : Outcome of in vitro culture of fresh and frozenthawed human testicular spermatozoa. Hum. Reprod., 1997, $12: 1667-1672$.

49. LOPES S., SUN J. G., JURISICOVA A., MERIANO J., CASPER R.F. : Sperm deoxyribonucleic acid fragmentation is increased in poor-quality semen samples and correlates with failed fertilization in intracytoplasmic sperm injection. Fertil. Steril., 1998, 69 : 528-532.

50. LUDWIG A.K., KATALINIC A., STEINBICKER V., DIEDRICH K., LUDWIG M. : Antenatal care in singleton pregnancies after ICSI as compared to spontaneous conception: data from a prospective controlled cohort study in Germany. Hum. Reprod., 2005, Nov 25 ; (Epub ahead of print).

51. MCLACHAN R., ROYCE P. : The medical consequences of vasectomy. Curr. Obstet. Gynaec., 1996, $6: 107-110$.

52. McVICAR C., O'NEILL D., McCLURE N., CLEMENTS B., McCULLOUGH S., LEWIS S. : Effects of vasectomy on spermatogenesis and fertility outcome after testicular sperm extraction combined with ICSI. Hum. Reprod., 2005, 20 : 27952800 .

53. MOSSAD H., MORSHEDI M., TONER J.P., OEHNINGER S. : Impact of cryopreservation on spermatozoa from infertile men: implications for artificial insemination. Arch. Androl., 1994, 33 : 51-57.

54. MOOSANI N., PATTINSON H.A., CARTER M.D. Chromosomal analysis of sperm from men with idiopathic infertility using sperm karotyping and fluoresence in situ hybridization. Fertil. Steril., 1995, $64: 811-817$.

55. MORRIS I.D., ILOTT S., DIXON L., BRISON D.R. : The spectrum of DNA damage in human sperm assessed by single cell gel electrophoresis (Comet assay) and its relationship to fertilization and embryo development. Hum. Reprod., 2002, 17 : 990-998.

56. NICOPOULLOS J.D., GILLING-SMITH C., ALMEIDA P.A. RAMSAY J.W. : Effect of time since vasectomy and materna age on intracytoplasmic sperm injection success in men with obstructive azoospermia after vasectomy. Fertil. Steril., 2004 82 : 367-373.

57. NICOPOULLOS J.D., RAMSAY J.W.A., ALMEIDA P.A., GILLING-SMITH C. : Assisted reproduction in the azoospermic couple (Review). Br. J. Obs. Gynaec., 2004, 111 : 1190-1203.

58. NIJS M., OMBELET W. : Intracytoplasmic sperm injection in assisted reproductive technology : an evaluation. Hum. Fertil., 2000, $3: 221-225$

59. NOGUEIRA D., BOURGAIN C., VERHEYEN G., VAN STEIRTEGHEM A.C. : Light and electron microscopic analysis of human testicular spermatozoa and spermatids from frozen and thawed testicular biopsies. Hum. Reprod., 1999, 14 : 20412049.

60. O'CONNELL M., MCCLURE N., LEWIS S.E.M. : The effects of cryopreservation on sperm morphology, motility and mitochondrial function. Hum. Reprod., 2002, 17 : 704-709.

61. OLDEROID N., DE ANGELIS P., WIGER R., CLAUSEN O. : Expression of $\mathrm{Bcl}-2$ family proteins and spontaneous apoptosis in normal human testis. Mol. Hum. Reprod., 2001, 7 : 403-
408.

62. O'NEILL D.A., McVICAR C.M., McCLURE N. et al. : Reduced sperm yield from testicular biopsies of vasectomised men is due to increased apoptosis. Fert. Steril., 2006 (provisional acceptance).

63. PASQUALOTTO F.F., ROSSI-FERRAGUT L.M., ROCHAC.C., ICONELLI A., ORTIZ V., BORGES E. : The efficacy of repeat percutaneous epididymal sperm aspiration procedures. J. Urol., 2003, 169 : 1779-2781.

64. POCCIA D. : Remodelling of nucleoproteins during gametogenesis, fertilization, and early development. Int. Rev. Cytol., 1986, $105: 1-65$

65. POTTS J., PASQUALOTTO F., NELSON D., THOMAS A.J., AGARWAL A. : Patients characteristics associated with vasectomy reversal. J. Urol., 1999, $161:$ 1835-1838.

66. PRINS G.S., DOLGINA R., STUDNEY P., KAPLAN B., ROSS L., NIEDERBERGER C. : Quality of cryopreserved testicular sperm in patients with obstructive and non-obstructive azoospermia. J. Urol., 1999, $161:$ 1504-1508.

67. RAMASAMY R., YAGEN N., SCHIEGEL P.N. : Structural and functional changes to the testis after conventional versus microdissection testicular sperm extraction. Urology, 2005, 65:1190-1194

68. RIMM A.A., KATAYAMA A.C., DIAZ M., KATAYAMA K.P. : A meta-analysis of controlled studies comparing major malformation rates in IVF and ICSI infants with naturally conceived children. J. Assist. Reprod. Genet., 2004, 21 : 437-443.

69. RODRIGUEZ I., ODY C., ARAKI K., GARCIA I., VASSALLI P.: An early and massive wave of germinal cell apoptosis is required for the development of functional spermatogenesis. EMBO J., 1997, $16: 2262-2270$.

70. SAKKAS D., URNER F., BIANCHI P.G. et al. : Sperm chromatin abnormalities can influence decondensation after intracytoplasmic sperm injection. Hum. Reprod., 1996, 11 : 837-843.

71. SAKKAS D., MANICARDI G., BIZZARO D., BIANCHI P.G. : Possible consequences of preforming ICSI with sperm possessing nuclear DNA damage. Hum. Fertil., 2000, 3 : 26-30.

72. SCHILL T., BALS-PRATSCH M., KUPKER W., SANDMANN J., JOHANNISSON R., DIEDRICH K. : Clinical and endocrine follow-up of patients after testicular sperm extraction. Fertil. Steril., 2003, $79:$ 281-286.

73. SCHLEGEL P.N., SU L.-M. : Physiological consequences of testicular sperm extraction. Hum. Reprod., 1997, 12 : 16881692.

74. SCHULZE W., THOMS F. KNUTH U.A. : Testicular sperm extraction: comprehensive analysis with simultaneously performed histology in 1418 biopsies from 766 subfertile men. Hum. Reprod., 1999, 14 (Suppl 1) : 82-96

75. SHIGENAGA M.K., HAGEN T.M., AMES B.N. : (1994) Oxidative damage and mitochondrial decay in aging. Proc. Natl Acad. Sci. USA, 1994, 91 : 10771-10778.

76. SHUFARO Y., PRUS D., LAUFER N., SIMON A. : Impact of repreated testicular fine needle aspirations (TEFNA) and testicular sperm extraction (TESE) on the microscopic morphology of the testis : an animal model. Hum. Reprod., 2002, 17 : 17951799.

77. SILBER S.J., VAN STEIRTEGHEM A.C., LIU J., NAGY Z., TOURNAYE H., DEVROEY P. : High fertilization and pregnancy rate after intracytoplasmic sperm injection with spermatozoa obtained from testicular biopsy. Hum. Reprod., 1995, 10 : 148-152.

78. SILBER S.J., NAGY Z., DEVROEY P., TOURNAYE H., VAN 
STEIRTEGHEM A.C. : Distribution of spermatogenesis in the testicles of azoospermic men : the presence or absence of spermatids in the testes of men with germinal failure. Hum. Reprod., 1997, $12: 2422-2428$.

79. SOUSA M., CREMADES N., SILVA J., et al. : Predictive value of testicular histology in secretory azoospermic subgroups and clinical outcome after microinjection of fresh and frozen-thawed sperm and spermatids. Hum. Reprod., 2002, 17 : 18001810.

80. SPANO M., BONDE J.P., HJØLLUND H.I. et al. : Sperm chromatin damage impairs human fertility. Fertil. Steril., 2000, 73 : 43-50.

81. ST-JOHN J.C., COOKE I.D., BARRATT C.L.R. : Mitochondrial mutations and male infertility. Nat. Med., 1997, 3 : 124-125.

82. STEELE E.K., McCLURE N., LEWIS S.E.M. : A comparison of the morphology of testicular, epididymal, and ejaculated sperm from fertile men and men with obstructive azoospermia. Fertil. Steril., 2000, $73: 1099-1103$.

83. STEELE E.K., KELLY J.D., LEWIS S.E.M., et al. : Testicular sperm extraction by Trucut needle and milking seminiferous tubules: a technique with high yield and patient acceptability. Fertil. Steril., 2000, $74: 380-383$.

84. STEELE E.K., ELLIS P.K., LEWIS S.E.M., MCCLURE N. : Ultrasound, antisperm antibody, and hormone profiles after testicular Trucut biopsy. Fertil. Steril., 2001, 75 : 423-428.

85. STEELE E.K., LEWIS S.E.M., McCLURE N. : Azoospermia 'to infinity and beyond'. Obstet. Gynaecol., 2002, $4: 71-75$.

86. STEGER K., SLAVOV M., FAILING K., WEIDNER W., BERGMANN M. : Effect of vasectomy on sperm nuclear chromatin condensation in the rabbit. J. Androl., 2005, $26: 289-295$.

87. TARLATZIS B.C., BILI H. : Survey on intracytoplasmic sperm injection : report from the ESHRE ICSI Task Force. Hum. Reprod., 1998, 13 (Suppl 1) : 165-177.

88. TEMPLE-SMITH P.D., SOUTHWICK G.J., YATES C.A., TROUNSON A.O., DE KRETSER D.M. : Human pregnancy by in vitro fertilization (IVF) using sperm aspirated from the epididymis. J. In Vitro Fert. Embryo Transf., 1985, 2 : 119-122.

89. TOURNAYE H., LIU J., NAGY P.Z. et al. : Correlation between testicular histology and outcome after intracytoplasmic sperm injection using testicular spermatozoa. Hum. Reprod., 1996, $11: 127-132$.

90. TOURNAYE H., VERHEYEN G. NAGY P. et al. : Are there any predictive factors for successful testicular sperm recovery in azoospermic patients. Hum. Reprod., 1997, $12: 80-86$.

91. TOURNAYE H., CLASEN K., AYTOZ A., NAGY Z., VAN STEIRTEGHEM A., DEVROEY $P$. : Fine needle aspiration versus open biopsy for testicular sperm recovery : a controlled study in azoospemic patients with normal spermatogenesis. Hum. Reprod., 1998, 13 : 901-904.

92. TWIGG J., FULTON N., GOMEZ E., IRVINE D.S., AITKEN R.J. : Analysis of the impact of intracellular reactive oxygen species generation on the structural and functional integrity of human spermatozoa : lipid peroxidation, DNA fragmentation and effectiveness of antioxidants. Hum. Reprod., 1998, 13 : 1429-1436.

93. TWIGG J.P., IRVINE D.S., AITKEN R.J. : Oxidative damage to DNA in human spermatozoa does not preclude pronucleus formation at intracytoplasmic sperm injection. Hum. Reprod., 1998, $13:$ 1864-1871.

94. UBALDI F., NAGY Z.P., RIENZI L. et al. : Reproductive capacity of spermatozoa from men with testicular failure. Hum. Reprod., 1999, $14:$ 2796-2800.
95. VERHEYEN G., NAGY Z., JORIS H., DE CROO I., TOURNAYE H., VAN STEIRTEGHEM A. : Quality of frozen-thawed testicular sperm and its preclinical use for intracytoplasmic sperm injection into in vitro-matured germinal-vesicle stage oocytes. Fertil. Steril., 1997, $67: 74-80$.

96. VERNAEVE V., TOURNAYE H., OSMANAGAOGLU K. et al. : Intracytoplasmic sperm injection with testicular spermatozoa is less successful in men with non-obstructive azoospermia than in men with obstructive azoospermia. Fertil. Steril., 2003, 79 : 529-533.

97. VISWANATH R., SHANNON P. : Do sperm cells age ? A review of the physiological changes in sperm during storage at ambient temperature. Reprod. Fertil. Dev., 1997, $9: 321-331$.

98. WALLACE D.C., LOTT M.R., SHOFFNER J.M., BALLINGER S. : Mitochondrial DNA mutations in epilepsy and neurological disease. Epilepsia, 1994, 35 (Suppl 1) : 43-50.

99. WARD W.S., COFFEY D.S. : DNA packaging and organization in mammalian spermatozoa - comparison with somatic-cells. Biol. of Reprod., 1991, 44 : 569-574.

100.WENG S.-L., YAYLOR S., MORSHEDI M. et al. : Caspase activity and apoptotic markers in ejaculated human sperm. Mol. Hum. Reprod., 2002, 8 : 984-991.

101.WENNERHOLM U.B., BERGH C., HAMBERGER L. et al. : Incidence of congenital malformations in children born after ICSI. Hum. Reprod., 15 : 944-948.

102.ZINI A., BIELECKI R., PHANG D., ZENZES M.T. : (2001) Correlations between two markers of sperm DNA integrity, DNA denaturation and DNA fragmentation, in fertile and infertile men. Fertil. Steril., 2001, $75: 674-677$.

\section{RESUME}

\section{Traitement de l'azoospermie obstructive par injection Intracytoplasmique d'un spermatozoïde}

\section{Sheena E.M. LEWIS}

L'injection intracytoplasmique d'un spermatozoïde (ICSI) permet de traiter virtuellement n'importe quel type d'infécondité masculine. A la différence de la Fécondation in vitro (FIV), son succès ne dépend pas de la concentration, de la mobilité ou de la morphologie des spermatozoïdes et la plupart des barrières physiques à la fécondation sont ainsi contournées. Puisque l'ICSI ne requiert pas de spermatozoïdes fortement mobiles, son usage a été maintenant élargi à l'utilisation des spermatozoïdes immatures des testicules et des épididymes. Une fécondation réussie, des grossesses, et des enfants en bonne santé ont tous été rapportés. Toutefois, persistent des inquiétudes à propos de l'innocuité de l'ICSI qui sont dues à sa brève existence clinique et à l'absence d'expérimentation sur des modèles animaux.

Le potentiel de fécondité masculine pour la reproduction assistée par ICSI ne peut pas être mesuré par les paramètres conventionnels. L'intégrité de l'ADN spermatique est, de façon grandissante, reconnue comme un indicateur 
plus utile. Des études ont montré que les spermatozoïdes ayant des taux élevés d'altération de l'ADN, ont des taux de fécondation plus faibles en FIV et en ICSI. Les spermatozoïdes avec une altération de l'ADN au-dessus d'un certain seuil sont associés à une augmentation du délai pour concevoir chez des couples par ailleurs apparemment féconds, et à un taux élevé de fausses-couches. On a montré que l'altération de l'ADN était liée à une segmentation embryonnaire défectueuse. Notre groupe a rapporté que l'ADN de spermatozoïdes provenant du testicule était moins fragmenté que l'ADN de spermatozoïdes provenant de l'épididyme, ce qui suggère l'utilisation préférée des premiers en ICSI.

En plus de l'ADN nucléaire (n), nous avons aussi évalué la qualité de l'ADN mitochondrial (mt) dans les spermatozoïdes testiculaires d'hommes avec azoospermie obstructive en cours d'ICSI.

Nous avons observé que les couples qui obtenaient une grossesse, avaient à la fois moins de délétions de l'ADNmt et moins de fragmentation de l'ADNn. Nous avons trouvé une relation inverse entre grossesse d'une part, et d'autre part, nombres de délétion de l'ADNmt et taille et fragmentation de l'ADNn des spermatozoïdes. Aucune relation n'a été observée avec les taux de fécondation. Avec ces données, nous avons établi un algorithme pour la prédiction de grossesses, basé sur la qualité de l'ADN, et l'ADNmt des spermatozoïdes.

Chaque année 40000 hommes ont une vasectomie au Royaume Uni, mais chaque année 2500 demandent une reperméabilisation pour fonder une seconde famille. Pour de tels hommes, la réversion de la vasectomie a récemment été remplacée en partie par la biopsie testiculaire, au moyen de l'aspiration de spermatozoïdes testiculaires à l'aiguille fine (TESA) ou de l'aspiration percutanée de spermatozoïdes épididymaires (PESA), réalisée en ambulatoire et utilisée ensuite en ICSI. Puisque ces hommes étaient auparavant des hommes féconds, on les a considérés comme ayant des spermatozoïdes "féconds". Toutefois, les taux de succès en conception assistée des partenaires de ces hommes n'ont été évalués que récemment. Nous avons montré une réduction significative des taux de grossesse clinique chez les partenaires des hommes qui avaient eu une vasectomie plus de 10 ans auparavant. II existe aussi des éléments qui suggèrent que la spermatogenèse est altérée de façon significative chez les hommes vasectomisés. Une diminution importante des spermatocytes, des spermatides et des spermatozoïdes a été observée. Nous avons trouvé que celle-ci était associée à une augmentation concomitante des marqueurs de l'apoptose, comme le Fas, FasL et Bax. La qualité des spermatozoïdes qui restent est aussi compromise. L'ADN des spermatozoïdes d'hommes vasectomisés présente des altérations substantielles qui augmentent avec le temps après la chirurgie.

L'auteur discute cette nouvelle indication de l'ICSI.

Mots clés : spermatozoïde testiculaire, azoospermie obstructive, vasectomie, $A D N$ nucléaire, $A D N$ mitochondrial 